\title{
Salmonella Count Changes of Poultry Farm Waste during different Stages and Seasons of Composting
}

\author{
I. A. Baba ${ }^{1 *}$, M. T. Banday ${ }^{1}$, H. M. Khan ${ }^{1}$, A. A. Khan ${ }^{1}$ and M. Ali ${ }^{2}$ \\ ${ }^{1}$ Division of Livestock Production and Management, Sheri-e-Kashmir University of \\ Agricultural Sciences and Technology of Kashmir, India \\ ${ }^{2}$ Faculty of Veterinary Sciences and Animal Husbandry Shuhama, Sheri-e-Kashmir University \\ of Agricultural Sciences and Technology of Kashmir, India \\ *Corresponding author
}

\begin{tabular}{|l|}
\hline Ke y w o r d s \\
Salmonella, Poultry \\
$\begin{array}{l}\text { Farm, Seasons of } \\
\text { Composting }\end{array}$ \\
\hline Article Info \\
\hline $\begin{array}{l}\text { Accepted: } \\
\text { 20 May 2018 } \\
\text { Available Online: } \\
\text { 10 June 2018 }\end{array}$ \\
\hline
\end{tabular}

\section{Introduction}

Poultry sector in India has become a fullfledged industry due to commercialization and intensification in production (Anon. 2015). Vigorous poultry farming activity generates huge volumes of poultry waste, which needs quick and prompt disposal to avoid different menaces born out of it (Ahuja, 2011). The poultry waste contains a wide range of infectious and pathogenic load and if properly not managed it can create bio-security problems for animals as well as humans (Glanville et al., 2006). Composting is a controlled natural process in which beneficial microorganisms (bacteria and fungi) reduce and transform organic waste into a useful end product called compost (Sander et al., 2002). Composting is recommended as an ecofriendly process with less cost and labour involvement and provides an opportunity to reduce the pathogenic load of the waste to a 
great extent by yielding a safe and secure end product (Michel et al., 1996). The objective of the study was to assess the Salmonella count changes in composting of poultry farm waste during different seasons.

\section{Materials and Methods}

The present study was carried out in the Division of Livestock Production and Management, Faculty of Veterinary Sciences and Animal Husbandry (SKUAST- Kashmir) under the agro-climatic conditions of Kashmir Valley. The site of experimentation was situated in the north western region of Srinagar (Jammu and Kashmir). Poultry farm waste (dead birds and poultry litter) was utilized to study the composting and fermentation experiments in two separate trails during summer and winter seasons. Composting of poultry litter was done in wooden bins (Mini composter) with a specification of 3 feet length $x 3$ feet width $\times 3$ feet height designed as per the method of Donald et al., (1996). The floor of the compost bin was made impervious to prevent seepage of leachiates and subsequent moisture and nutrient loss. The sidewalls of the compost bins were made up of country wooden planks of 4 to 5 inches wide and one inch thick. An air space of 1-2 inch was provided between wooden planks to aid sufficient aeration to the compost piles. Dead birds for the present study were collected from local poultry farms and stored at $-5^{\circ} \mathrm{C}$ till sufficient carcasses were made available to fill all the compost bins in a single day. Similarly, poultry litter was collected from poultry farm of LPM. Paddy straw (Oryza sativa) was used as a carbonaceous as well as bulking agent wherever it was required. Paddy straw was purchased from farmer's field and stored in advance. Four compost recipe treatments (with three replicates in each treatment) were formulated with addition of effective microbial culture (Lactobacillus plantarum,
Lactobacillus casei, Saccharomyces cerevisiae and Rhodopseudomonas palustris) in two treatments as shown in Table. 3.1. For Salmonella count changes the compost samples were collected at the time of loading (by mixing all the ingredients thoroughly and taking samples), at the end of primary stage and at the end of secondary stage in a serial polythene bags and sealed air tight. The samples were serially diluted in 10 fold steps using sterile triple glass distilled water. The Salmonella Shigella agar was used as selective media. The selective media was incubated aerobically for 1 day at $37^{\circ} \mathrm{C}$. The microbial numbers were expressed as $\log _{10}$ colony forming units per gram of sample (Quinn et al., 1992).

\section{Statistical analysis}

The data was statistically analyzed as per the methods suggested by Snedecor and Cochran (1996). SPSS software was used for comparing the means using one way ANOVA.

\section{Results and Discussion}

\section{Salmonella Count}

At initial stage, the Salmonella count ranged between $7.33 \log _{10} \mathrm{cfu}$ in $\mathrm{T}_{3}$ group (effective microbes) and $8.66 \log _{10}$ cfu in $\mathrm{T}_{2}$ group (with paddy straw) during winter season (Table. 1). During summer season the highest and lowest Salmonella count observed was $8.5 \log _{10}$ cfu in $\mathrm{T}_{1}$ group (control group) and $\mathrm{T}_{2}$ group and $7.08 \log _{10} \mathrm{cfu}$ in $\mathrm{T}_{3}$ group respectively (Plate. 4.3). The overall highest Salmonella count of $8.58 \log _{10}$ cfu was observed in $\mathrm{T}_{2}$. At the end of primary stage, the Salmonella count varied between $5.66 \log _{10} \mathrm{cfu}$ in treatment group $\mathrm{T}_{2}$ and $4.66 \log _{10} \mathrm{cfu}$ in $\mathrm{T}_{4}$ (with paddy straw with effective microbes). Similarly during summer season, the highest and lowest Salmonella count of $6.66 \log _{10}$ cfu and $5.33 \log _{10}$ cfu was observed respectively in $T_{1}$ and $T_{3}$ (with 
effective microbes). The overall lowest Salmonella count of $5.16 \log _{10} \mathrm{cfu}$ was observed in $\mathrm{T}_{3}$ group (with effective microbes). At the end of secondary stage of composting, the highest and the lowest Salmonella count of $2.0 \log _{10} \mathrm{cfu}$ and $1.41 \log _{10} \mathrm{cfu}$ was observed in treatment group $\mathrm{T}_{1}$ and $\mathrm{T}_{4}$ respectively. Similarly during summer season the highest and lowest Salmonella count observed was 1.5 $\log _{10} \mathrm{cfu}\left(\mathrm{T}_{2}\right.$ and $\left.\mathrm{T}_{3}\right)$ and $1.25 \log _{10} \mathrm{cfu}\left(\mathrm{T}_{4}\right)$ respectively. The overall lowest Salmonella count of $1.33 \log _{10}$ cfu was observed in $\mathrm{T}_{4}$ (containing paddy straw with effective microbes). The Salmonella count significantly $(\mathrm{P}<0.05)$ reduced from initial to secondary stage of composting in all treatment groups during both the seasons (Table. 3).

\section{Salmonella Count}

Salmonella is selected as representative pathogen as it is generally present in all animal wastes. The estimated Salmonella count at initial stage varied from 7.33 $\log _{10} \mathrm{cfu} / \mathrm{g}$ (in $\mathrm{T}_{3}$ treatment group) to 8.66 $\log _{10} \mathrm{cfu} / \mathrm{g}$ (in $\mathrm{T}_{2}$ treatment group) during winter and $7.08 \log _{10} \mathrm{cfu} / \mathrm{g}$ (in $\mathrm{T}_{3}$ treatment group) and $8.5 \log _{10} \mathrm{cfu} / \mathrm{g}$ (in $\mathrm{T}_{1}$ and $\mathrm{T}_{2}$ treatment groups) $\log _{10} \mathrm{cfu} / \mathrm{g}$ during summer seasons (Table. 2). At primary stage the count ranged between 4.66 (in $\mathrm{T}_{4}$ treatment group) and $5.83 \log _{10} \mathrm{cfu} / \mathrm{g}$ (in $\mathrm{T}_{1}$ treatment group) during winter and $5.33 \log _{10} \mathrm{cfu} / \mathrm{g}$ (in $\mathrm{T}_{3}$ treatment group) and $6.66 \log _{10} \mathrm{cfu} / \mathrm{g}$ (in $\mathrm{T}_{1}$ treatment group) during summer season. Similarly at the final stage the Salmonella count with highest and lowest values were $1.41 \log _{10} \mathrm{cfu} / \mathrm{g}$ (in $\mathrm{T}_{4}$ treatment group) and 2.0 $\log _{10} \mathrm{cfu} / \mathrm{g}$ (in $\mathrm{T}_{1}$ treatment group) $\log _{10} \mathrm{cfu} / \mathrm{g}$ during winter and $1.25 \quad \log _{10} \mathrm{cfu} / \mathrm{g}$ (in $\mathrm{T}_{4}$ treatment group) and $1.41 \log _{10} \mathrm{cfu} / \mathrm{g}$ (in $\mathrm{T}_{1}$ treatment group) during summer season. There was a significant $(\mathrm{P}<0.05)$ drastic reduction of Salmonella count from initial to final stages of composting during both winter and summer seasons. At secondary stage the highest reduction of Salmonella count was noticed in the final end product of compost in both the seasons (Table. 3). It was observed that season had no effect on Salmonella count at any of the stages of composting but a drastic reduction was observed in overall Salmonella count from initial to final stages of composting. It was also observed that there was drastic reduction in Salmonella count from initial to final stage of composting with highest reduction at secondary stage followed by primary stage indicating the mixing of compost mixture eliminated maximum number of organisms. The highest reduction among all the treatments was in $\mathrm{T}_{4}$ treatment group (having paddy straw and effective microbial culture). The destruction of Salmonella by composting process was reported earlier by Murphy (1988); Cummins et al., (1993), and Harper et al., (2001).

Table.1 Different Treatments Combination for Composting

\begin{tabular}{|l|l|}
\hline Treatments & Description \\
\hline Treatment 1 & Dead birds + Poultry litter (Control) \\
\hline Treatment 2 & Dead birds + Poultry litter + Paddy Straw \\
\hline Treatment 3 & Dead birds + Poultry litter + Effective Microbes \\
\hline Treatment 4 & Dead birds + Poultry litter +Paddy straw + Effective Microbes
\end{tabular}


Table.2 Salmonella count during different stages and seasons of composting as $\log _{10} \mathrm{cfu} / \mathrm{g}$ (Mean \pm SE)

\begin{tabular}{|c|c|c|c|c|c|c|c|c|c|}
\hline \multirow[t]{2}{*}{ Treatment } & \multicolumn{3}{|c|}{ Initial Stage } & \multicolumn{3}{|c|}{ Primary stage } & \multicolumn{3}{|c|}{ Secondary stage } \\
\hline & Winter & Summer & Overall & Winter & Summer & Overall & Winter & Summer & Overall \\
\hline $\mathbf{T}_{1}$ & $8.50 \pm 0.57$ & $8.50 \pm 0.57$ & $8.50 \pm 0.05$ & $5.83 \pm 0.33$ & $6.66 \pm 0.72$ & $6.24 \pm 0.40$ & $2.00 \pm 0.02$ & $1.41 \pm 0.16$ & $1.70 \pm 0.03$ \\
\hline $\begin{array}{c}\mathrm{T}_{2} \\
\text { (Paddy Straw) }\end{array}$ & $8.66 \pm 0.92$ & $8.50 \pm 0.76$ & $8.58 \pm 0.12$ & $5.66 \pm 0.44$ & $5.83 \pm 0.33$ & $5.74 \pm 0.14$ & $1.75 \pm 0.25$ & $1.50 \pm 0.28$ & $1.62 \pm 0.10$ \\
\hline $\begin{array}{c}\mathrm{T}_{\mathbf{3}} \\
\text { (Effective } \text { Microbes) }\end{array}$ & $7.33 \pm 0.72$ & $7.08 \pm 0.65$ & $7.20 \pm 0.24$ & $5.00 \pm 0.28$ & $5.33 \pm 0.44$ & $5.16 \pm 0.19$ & $1.91 \pm 0.36$ & $1.50 \pm 0.28$ & $1.70 \pm 0.09$ \\
\hline $\begin{array}{c}\mathrm{T}_{4} \\
\text { (Paddy Straw+ } \\
\text { Effective Microbes) }\end{array}$ & $8.00 \pm 0.28$ & $7.75 \pm 0.20$ & $7.87 \pm 0.29$ & $4.66 \pm 0.33$ & $5.75 \pm 0.20$ & $5.20 \pm 1.32$ & $1.41 \pm 0.30$ & $1.25 \pm 0.14$ & $1.33 \pm 0.02$ \\
\hline
\end{tabular}

Figures with different small superscripts row wise and capital superscripts column wise differ significantly $(\mathrm{P}<0.05)$.

Table.3 Change in Salmonella count $\left(\log _{10} \mathrm{cfu} / \mathrm{g}\right)$ from initial to secondary stages of composting during different seasons (Mean \pm SE)

\begin{tabular}{|c|c|c|c|c|c|c|}
\hline \multirow[t]{2}{*}{ Treatment } & \multicolumn{3}{|c|}{ Winter } & \multicolumn{3}{|c|}{ Summer } \\
\hline & Initial stage & Primary stage & Secondary stage & Initial stage & Primary stage & Secondary stage \\
\hline$\overline{T_{1}}$ & $8.50 \pm 0.57^{\mathrm{a}}$ & $5.83 \pm 0.33^{b}$ & $2.00 \pm 0.02^{\mathrm{c}}$ & $8.50 \pm 0.57^{\mathrm{a}}$ & $6.66 \pm 0.72^{a}$ & $1.41 \pm 0.16^{\mathrm{b}}$ \\
\hline $\begin{array}{c}\mathrm{T}_{2} \\
\text { (Paddy Straw) }\end{array}$ & $8.66 \pm 0.92^{\mathrm{a}}$ & $5.66 \pm 0.44^{b}$ & $1.75 \pm 0.25^{\mathrm{c}}$ & $8.50 \pm 0.76^{\mathrm{a}}$ & $5.83 \pm 0.33^{b}$ & $1.50 \pm 0.28^{c}$ \\
\hline $\begin{array}{c}\mathrm{T}_{3} \\
\text { (Effective Microbes) }\end{array}$ & $7.33 \pm 0.72^{\mathrm{a}}$ & $5.00 \pm 0.28^{b}$ & $1.91 \pm 0.36^{\mathrm{c}}$ & $7.08 \pm 0.65^{\mathrm{a}}$ & $5.33 \pm 0.44^{\mathrm{a}}$ & $1.50 \pm 0.28^{b}$ \\
\hline $\begin{array}{c}\mathrm{T}_{4} \\
\text { (Paddy Straw + } \\
\text { Effective Microbes) }\end{array}$ & $8.00 \pm 0.28^{\mathrm{a}}$ & $4.66 \pm 0.3^{b}$ & $1.41 \pm 0.30^{c}$ & $7.75 \pm 0.20^{\mathrm{a}}$ & $5.75 \pm 0.20^{b}$ & $1.25 \pm 0.14^{\mathrm{c}}$ \\
\hline
\end{tabular}

Figures with different small superscripts row wise and capital superscripts column wise differ significantly $(\mathrm{P}<0.05)$. 
The reduction of bacteria to the extent of 3 MPN/4 g dry solid has been reported earlier by Farrel (1993) from 100 million to 1 viable cell by McCaskey (1994), no viable bacteria by Donald et al., (1996); Tiquia et al., (1998) and Das et al., (2002).

The Salmonella count was either drastically reduced or not detected in the end product of composting during both winter and summer seasons of composting.

\section{Acknowledgement}

Authors are highly thankful to the Dean, Faculty of Veterinary Sciences and Animal Husbandry and Head Division of LPM for providing financial help for this study.

\section{References}

Ahuja S M. 2011. Cost Effective Solution for Carcass Disposal in India. International Journal of Environmental Sciences 1(6): 1-6.

Anonymous. 2015. Poultry News: Indian Broiler Production Projected to Increase in 2016. The poultry site, 14th October, 2015.

Cummins, C G., Wood, C. W. and Delaney, D. P. 1993. Co-composted poultry mortalities and poultry litter: Composition and potential value as a fertilizer. Journal of Sustainable Agriculture, 4(1): 7-18.

Das, K C., Minkara, M. Y., Melear, N. D. and Tollner, E. W. 2002. Effect of poultry litter amendment on hatchery waste composting. Journal of Applied Poultry Research, 11(2): 282-290.

Farrell, J B. 1993. Faecal pathogen control during composting. In: H.A.J. Hoitink and H.M. Keener. (Editors). Science and engineering of composting; design, environmental, microbiological and utilization aspects. Wooster, Ohio: The Ohio State University, pp. 282-300.

Glanville T D., Richard T L., Harmon J D., Reynolds D L., Ahn H K. 2006. Environmental Impacts and Biosecurity and Composting for Emergency Disposal of Livestock Mortalities. Iowa State University, USA.

Harper, A.F., Estienne, M.J. and Collins, E.R. 2001. Composting as an environmentally safe means of dead pig disposal on Virginia swine farms. Suffolk. Virginia Tech Tidewater Agricultural Research and Extension Center. pp. 2-5.

McCaskey, T.A. 1994. Dead bird composting. Final report for Contract USDA-432D81-1-561, Auburn University, pp. 27.

Michel FC Jr., Forney LJ, Huang AJ, Drew S, Czuprenski M, Lindeneg JD, Reddy CA. Effects of turning frequency, leaves to grass ratio and windrow vs pile configuration on composting of yard trimmings. Compost Sci Util 1996; 4: 26-43.

Murphy, D.W. 1988. Composting as a dead bird disposal method. Poultry Science, 67(2): 124.

Quinn, P. J., Carter, M. E., Markey, B. K and Carter, G. R. 1992. Clinical Veterinary Microbiology. Mosby-Year book Europe Limited. London, pp. 61-65.

Sander, JE, Warbington, M.C and Myers, LM. Selected methods of animal carcass disposal. Journal of American Veterinary Medical Association, 2002. 220(1), 1003-1005.

Snedecor, GW and Cochran, WG. Statistical Methods 8th Edition, Iowa State Press, Ames, Iowa, USA. 1994. pp: 254-268.

Tiquia, S.M., Tam, N.F.Y. and Hodgkiss, I.J. 1998. Changes in chemical properties during composting of spent pig litter at different moisture contents. Agriculture Ecosystems and Environment, 67(1): 79-89. 


\section{How to cite this article:}

Baba I. A., M. T. Banday, H. M. Khan, A. A. Khan and Ali M. 2018. Salmonella Count Changes of Poultry Farm Waste during different Stages and Seasons of Composting. Int.J.Curr.Microbiol.App.Sci. 7(06): 2232-2237. doi: https://doi.org/10.20546/ijcmas.2018.706.265 